\title{
Consulting completed: temporal aspects of expertise in urban development during times of fast policies
}

\author{
Anne Vogelpohl \\ Department of Geography, University of Hamburg, Bundesstr. 55, 20146 Hamburg, Germany \\ Correspondence to: Anne Vogelpohl (anne.vogelpohl@uni-hamburg.de)
}

Received: 30 August 2016 - Revised: 14 January 2017 - Accepted: 16 January 2017 - Published: 2 February 2017

\begin{abstract}
Consultants, especially management consultants with their expertise in markets and entrepreneurial thinking, have gained a new role in urban policy. Urban politicians, facing ever-increasing international competition as well as diverse urban crises, search for immediate solutions, at times drawing on professional advice. This paper introduces the role of management consultants in urban policy in the context of fast policies. These new policies are often both developed over short periods of time and built upon predesigned concepts. Taking six German cities as examples, I frame the impact both of the duration of consultancy projects and of the moment when the consultants leave as temporal aspects of expertise that significantly influence how the external knowledge eventually shapes local political practices. I show that short-term consulting first causes a stimulus for change but then primarily results in an ambivalent amalgamation of professionalization and selectivity as permanently fast modes of everyday policymaking.
\end{abstract}

\section{Introduction}

Immediate answers to emerging conflicts and quick solutions to pressing problems are often sought after by politicians, local and regional alike, when difficult issues are publicly discussed. Experts' advice is considered useful during such situations, in order to both provide orientation and suggest possible solutions. In the urban realm, socioeconomic problems that require new policies, including the constraining effects of local austerity policies, a deepening global interurban competition and job losses through the now already decades-long process of deindustrialization, have given rise to a new type of expert in urban politics: management consultants. Around the turn of the millennium, global management consultancies like McKinsey \& Company or Roland Berger Strategy Consultants discovered a new field of action in urban and regional policies. These firms act globally and now regularly advise local and regional governments in cities like Hamburg, Mumbai and Chicago or federal states like Baden-Wuerttemberg or Andhra Pradesh. Urban politicians and administrations who face socioeconomic challenges and the global entrepreneurialization of cities are likewise increasingly interested in expert knowledge on entrepreneurial thinking.
Political decision-making processes, however, are time consuming, and many months and indeed years may pass before new policies take effect. However, consulting projects usually last only a few months and the lengthy process of translating expert knowledge into concrete programs and projects of urban development only begins after the consultants have left. In this paper I argue that the type of transition points to the eventual relevance of the consulting projects to urban policies. The transition is decisive for the local acceptance as well as for the practical effectiveness of external expertise. Taking six German cities and regions that were advised either by McKinsey or Roland Berger ${ }^{1}$ as examples, I will discuss the moment when expert knowledge is transferred into political practice. Conceptually, the analysis is framed by a brief review of the emerging fast policy debates and the role of experts within these (Sect. 2). Empirically, I first introduce the six cases of urban management consulting and my methodical approach before elaborating on their

\footnotetext{
${ }^{1}$ When the consultancy names "McKinsey" and "Roland Berger" are mentioned in this paper, I am referring to the companies and the respective consultants in charge, not to the persons James O. McKinsey $\left(* 1889,{ }^{\dagger} 1937\right)$ and Roland Berger $\left({ }^{*} 1937\right)$.
} 
respective approaches and duration to discern process- and model-oriented consulting logics (Sect. 3.1). I then analyze three types of transition from expert knowledge to praxis prepared, sudden and surprising transitions - in order to illustrate varieties of intertwining external and local knowledge (Sect. 3.2). Finally, I trace the policy effects of the external advice during the policy process to demonstrate which types of expert consultation eventually effect which types of practical policies (Sect. 3.3). The simultaneous discussion of the content and the processes of consulting projects finally allows for a differentiated consideration of the role of large management consultancies in the standardization and acceleration of urban policies (Sect. 4).

\section{The rise of fast urban policies and the demand for consultants}

Increased international competition and multiple urban crises are two mutually reinforcing conditions underlying today's assumed need for robust, data-based comparisons between cities that are understood as necessary for identifying urban key problems and pinpointing solutions. On the one hand, international competition for residents and investment since the late 1970s caused a deep shift in urban policy from the orchestration of growth and its social effects towards attempts to position cities as places having an inherently good business climate (Harvey, 1989; MacLeod, 2011). Effects range from the qualitative design and marketing of positive spatial imaginaries (Baker and Ruming, 2015; Jonas, 2014) to quantitative number crunches and calculative standardizations of local markets (Bitterer and Heeg, 2015). On the other hand, urban crises fundamentally reshaped the framework for local policies in two waves. First, beginning in the late 1970s, deindustrialization induced economic downturns, population declines and job losses (Läpple, 2006). Consequently, urban policies were increasingly redirected towards promoting promising economic branches, including selling soft locational factors and branding. Second, since the global economic and financial crisis of 2008, tightened municipal budgets and self-imposed local debt brakes set off a range of austerity policies (MacLeavy, 2011; Bischoff, 2012; Peck, 2012). Austerity policies include cutbacks in youth services, conceptualizing welfare as matter of expense as well as a stronger profit orientation in municipally owned corporations. These two key conditions - international competition and urban crises - characterize the wider trend of an urban neoliberalization that subjects more and more aspects of urban society and space to market mechanisms (Brenner et al., 2010; Harvey, 2004; Belina et al., 2013).

Fast policies offer one crucial answer to the new challenges of internationalization and to tackling crises. Policies are fast in terms of the velocity of the policy process itself, as Kuus (2015:838) notes: "The world of policymaking is fast. Information moves rapidly, deadlines are short, texts are drafted quickly." They are also fast in terms of using standard solutions, applying the same formulas to address novel issues in urban development. Festivals, smart city plans and privatization are examples of these standard solutions which Peck and Theodore (2015:xv) label "silver-bullet policies" - policies widely considered to be appropriate and successful and therefore not requiring a long period of reflection or testing. In their recent book Fast Policy - Experimental Statecraft at the Thresholds of Neoliberalism, Peck and Theodore (2015) explore this latter type of fast policy by following the global circulation of the micro-credit program "conditional cash transfers (CCTs)" as well as of "participatory budgeting (PB)". Fast policies, as emphasized in their analysis, are not synonymous with convergence and always the exact same political and policy processes. Instead, they emphasize that local policies are very closely globally interconnected. Integrating Kuus' observation of rapid decisions and rapid program designs, the concept of fast policy here grasps both the quick process of policy formulation as well as the adaption of predesigned policies.

The idea of fast policies is embedded in the wider literature on policy mobilities, an approach that focuses the global traveling of ideas and practices through a complex network of politicians, state's officers, consultants, journalists, planners, etc. (McCann, 2011; Peck and Theodore, 2010; see also Hurl, 2017, in this Special Issue). Experts - in the most general sense as persons with a specialized knowledge, but without responsibility for implementation and effects - have become influential agents for generating and, more often, spreading ideas as well as programmatic plans. Experts make policies fast. They are part of the global "social infrastructure" (Peck and Theodore, 2015:xv) that popularize and advertise certain policies. Examples include local officials who import harm reduction drug policies (McCann and Temenos, 2015), management consultants who regularly recommend cluster strategies (Jonas, 2014; Vogelpohl, 2016) and think tanks that spread neoliberal thinking (Mitchell, 2009; Peck, 2010). The experts' role in all these cases is to identify and label existing problems, to develop solutions, to provide access to information about existing solutions and to customize this information to local conditions. In sum, experts play a pivotal part in defining corridors for urban policymaking.

Consultants are a specific type of expert. Consulting activity implies a knowledge gap between the advisors on the one hand and the advice-seekers on the other, and this knowledge gap is the reason for direct interactions between the two. Thus consulting activity differs from academic research, public intellectual debates or journalism. Even though all experts involved in these fields build on knowledge as a key resource for their productivity, consultants directly offer and, in most cases, sell their knowledge directly to persons and organizations seeking advice. Their knowledge is sought after because they are considered to possess global experience in difficult situations, supposedly rendering them among the few able to disentangle complexities (Prince, 2012). Conse- 
quently, the consultants' role usually is to prepare the legitimation for decisions (Schützeichel, 2008) - decisions that are then eventually taken by responsible persons such as CEOs or elected politicians.

Consulting is increasingly utilized in making public policies, too. While sociologist Resch (2005) explains this through privatization and greater (self-imposed) pressure for political reform, former undersecretary of the German Federal Department for Urban Development Sinz (2011) identifies the increase with a need for faster political answers. The consultants Bill and Falk (2006), however, emphasize new types of initializing business contacts and customer acquisition within the consulting business. Very different interests are thus interwoven in a policy consulting project. This is especially true when management consultants, who are the focus of this paper, are contracted, because their primary field of expertise is in giving advice to companies to enhance their economic performance. They are experts in market mechanisms, creating a wide demand for their knowledge in neoliberalized times, as more and more spheres of life are organized according to market principles. Today, management consultancy firms such as McKinsey, Booz \& Company, Arthur D. Little or Roland Berger regularly offer their advice in areas like culture and arts, natural resources and certainly public policies. They therefore began labeling themselves as "strategy consultants" in more general terms. Additionally, consultancies publish books and magazines, for example on urbanization, digitalization or demographic change in order to gain visibility as experts for urban and regional development. As Saint-Martin (2012:454), who has extensively studied the role of management consultants in government restructuring and in introducing new public managementprinciples, asserts: "The book is a tool of the consultant."

Although management consultants' engagement in urban and regional strategic planning has not escaped notice (Einig et al., 2005; Rügemer, 2004; Wiechmann, 2008), "[w]ork on policy consultancies is thin on the ground," as Prince (2012:196) observed some years ago, with an explicit focus on geographic research. Since then, the research on the role of private experts and also on consultants influencing governmental policies is slowly evolving. This emerging field of research is closely linked to global social developments such as new waves of privatization, sustainability approaches or austerity politics (Parker et al., 2014; Petts and Brooks, 2006; Raco, 2013; see also Kipping and Wright, 2012). In times of austerity, intensified privatization - in the form of public-private partnerships (PPP) - and an increased influence of private sector experts are mutually reinforcing. This is particularly evident in times when private capital misses investment opportunities. Consequently, private capital is frequently invested in public welfare and infrastructure programs with the hope for robust and reliable revenues - and the private sector increasingly lobbies for PPP (Raco, 2013:89ff.). Furthermore, austerity and related cutbacks in public departments have created the need for outsourcing planning tasks so that private sector consultants manage key urban and regional planning projects today (Raco et al., 2016).

In the context of fast urban policies, several aspects of temporality regarding the use of consultants are relevant. A short phase of consulting promises a subsequent intensified velocity of the policy process. Analyses outsourced to professional analysts, good access to databases on "best practices" and a convincing vocabulary give reason to expect an accelerated political decision. Especially in times of crisis, when pressing problems require immediate reactions, external advice from persons who seem to possess the appropriate knowledge is welcome. The literature on consulting, however, ascribes this ability mainly to public research institutes. In Germany, the literature's primary focus is on research departments under the control of the various federal ministries (Ressortforschung), as they are able to extensively study phenomena and developments long before the issues become politically relevant (Göddecke-Stellmann, 2011; Sinz, 2011). According to the positive appraisal of (public) consulting in this literature, although the consulting project itself might be short, the preceding analytical work is appropriately lengthy and thorough.

From a more critical perspective, however, the prompt delivery of answers and solutions is derived not from anticipatory analyses but rather from copying and modifying projects from elsewhere. Compared to public research institutes, management consultants are usually regarded as experts who build on their global experience with similar cases - and bear the downside of potentially providing advice that is far too standardized. Unable to sufficiently take the local geographic and historical context into account, this kind of mobilized policy is problematic and these policies often fail (Dolowitz and Marsh, 2000; Kuus, 2015). Despite evaluating the benefits of consulting differently, both accounts emphasize that consultants significantly accelerate the policy process - except when used as a deliberative slowdown in order to postpone decisions. Using consultants can sometimes also aim to play with time. In these cases, a consulting project provides the opportunity to procrastinate decisions (for example, prior to elections) or to blur responsibilities (Rehfeld, 2005; Resch, 2005; Schützeichel, 2008).

The following empirical analysis seeks to assess the temporal conditions and effects of consulting projects in strategic urban development in German cities. Understood as fast policy, I address both aspects of velocity - the short-term nature of the projects and the adaption of ready-made policies. In the following sections, three central questions will be discussed. First, how long did the consulting projects last and how far were globally renowned policies interconnected with local geographical and historical conditions (Sect. 3.1)? Second, how isolated was the consultants' work from local stakeholders and residents and how was the transition from (temporary) experts' advice to (continuing) everyday political practice organized (Sect. 3.2)? Lastly, to what extent did 


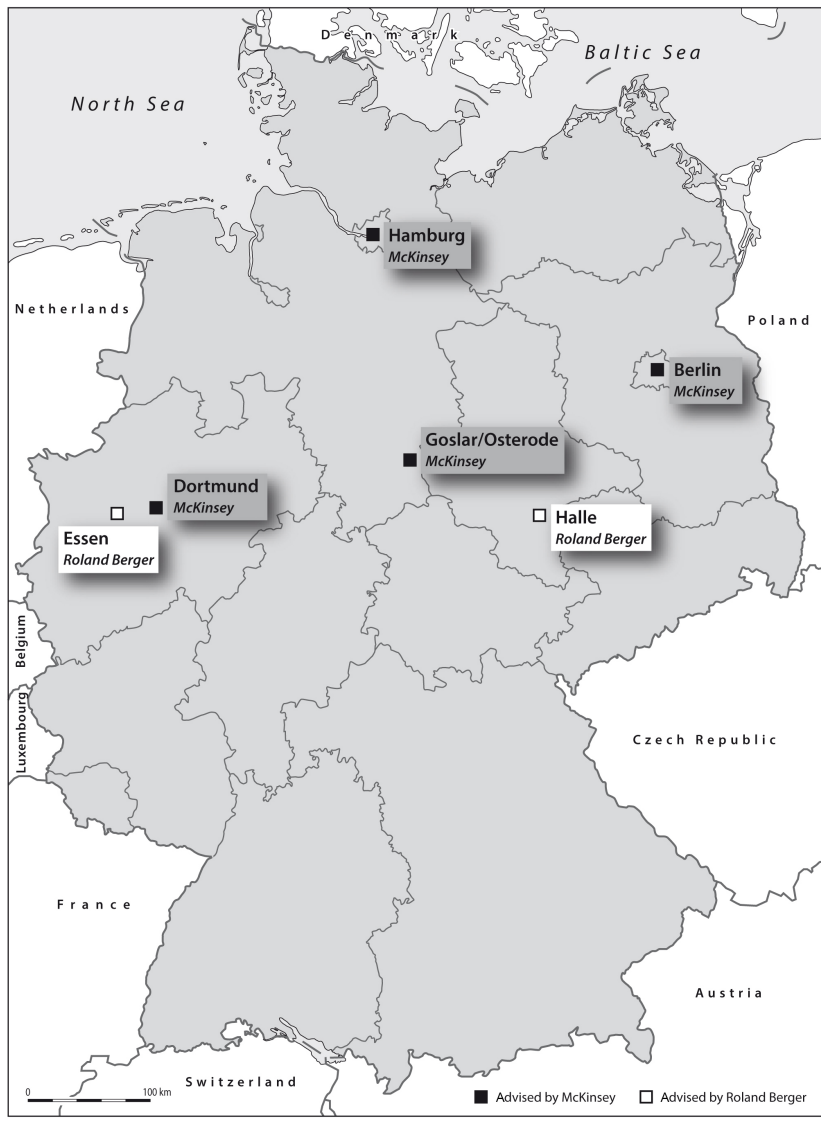

Figure 1. Map of the six case studies. Cartography: Claus Carstens.

the consulting project eventually influence local policy programs and what general type of policy takes shape through this influence (Sect. 3.3)?

\section{McKinsey and Roland Berger in German cities: accelerating and channeling urban strategic policies}

McKinsey \& Company and Roland Berger Strategy Consultants are the two management consultancies that regularly advise (urban) politicians and administrations in Germany. For the analysis of their role in guiding urban strategies, I chose six cases (see Fig. 1) that share certain similarities and differ in other respects. These six cases are the sample for a broader project investigating the diverse roles of management consultancies in strategic urban development in Germany.

A declining economy provides the background for all the cases analyzed here. In Dortmund and Halle the urban crisis was perceived as concrete because major plants were closed in the steel and chemical industries respectively; in Hamburg, Berlin, Goslar/Osterode and Essen the crisis was perceived as consequence of a general economic change due to globalization and tertiarization of the economy. I chose these cases because, in the context of these local dilemmas, globally operating management consultants either were asked for advice or offered their services, whether through public tender or unsolicited - a situation that emerges approximately every other year in a German city or region. Apart from the thematic similarity across all cases, I chose three cases (Dortmund, Hamburg and Halle) where projects had been initiated about 15 years ago, allowing for a better insight into mediumterm developments and effects of the consulting projects, and three cases that are more recent, making a deeper analysis of involved participants, processes and conflicts feasible. In both periods of time, three different types of financing were chosen in order to include all typical forms of financing and their potential effects on the consulting project's relevance. In Dortmund and Essen, local enterprises paid for the consultants privately, whereas in Hamburg and Berlin the consultancy presented pro-bono studies which were neither commissioned nor paid for. Furthermore, in Halle as well as in the cooperating districts of Goslar and Osterode in the West Harz, consultants were publicly paid by municipal and federal government budgets respectively. Table 1 provides an overview over the cases in focus.

The following examination is grounded in a broad empirical basis - documentary analyses of the consulting and policy papers and 41 interviews with 46 persons from all involved areas: 5 consultants, 6 politicians, 17 local officers, 5 critics and 13 other case-specific persons who were involved either in the consulting process or in projects resulting from these. The interviews were held between July 2012 and September 2015 and analyzed according to the documentary method which explicitly aims to reveal interviewees' convictions and beliefs that are not necessarily articulated as such (Nohl, 2012). Additionally, this method provides tools for classifying a successive account of common experiences (NentwigGesemann, 2013). Therefore, I first identified all interview sections in which temporal aspects filtered through, for example in reference to fast processes or moments of change. I then compared these sections and, through the search for variations, eventually developed types. The concrete parameters for discerning different types are addressed in the analysis that now follows.

\subsection{Process and model orientation: impacts of the consulting project's duration}

Management consultants usually begin their projects by gathering a vast amount of qualitative and quantitative data from data pools, existing policy papers and interviews with decision makers. Then, relatively quickly, they focus in on a future vision for the city as an economically thriving locale with a fascinating image that hosts cutting edge economic branches. These future outlines are often labeled Hamburg Vision 2020, Essen.2030 and the like. Through interconnecting the consulting project's duration and eventual formal results (see Table 1) two types of consulting logics are revealed 


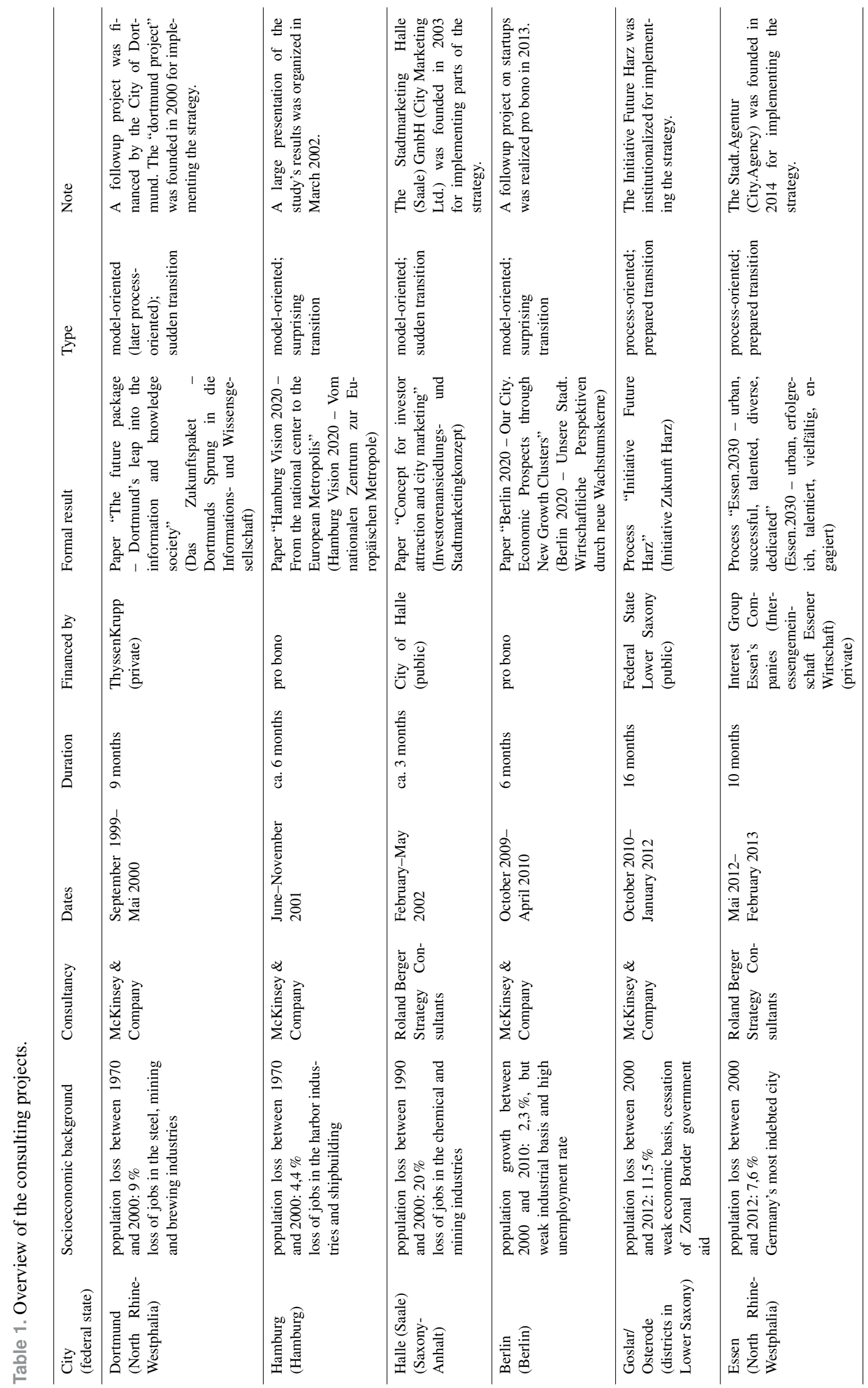


through how local officers describe their chances of participating in evaluating the current situation and possible future plans. The key parameter for discerning the two consulting logics thus was the intensity of cooperation.

The cases of Goslar/Osterode and Essen, the longest projects on which consultants worked - for 16 and 10 months respectively - were "process oriented". Process orientation implies both a successive definition of the concrete problems to be addressed and an incremental design of possible solutions, preferably by including diverse local stakeholders. Thus, as far as possible, predefined questions, concepts and answers were avoided. The officers of today's institutionalized Initiative Future Harz (Initiative Zukunft Harz, IZH) emphasize that, after the Federal State Lower Saxony decided to implement a consulting project to address the weak economy in the West Harz, they initiated an open process, interviewing more than 100 local entrepreneurs, politicians and community representatives to define "really bottom-up which topics shall be treated in the state's initiative"2 (Interview GOS36c_admin). In a similar vein, an officer in Essen describes Roland Berger's contribution as "knowledge and experience in such processes, in steering processes; no enhancement of contents - that was made by others" (Interview E22b_admin).

In contrast, the cases Dortmund, Hamburg, Halle and Berlin were "model oriented". In Halle, very early, the Roland Berger consultants pursued a creativity and attractiveness approach. A key statement was "Halle's weaknesses lie less in the product than in its image and marketing" (Roland Berger, 2002:21). From this standpoint, they developed their solutions (namely, setting up a city marketing agency) within only 3 months and with only two or three consultants. The underlying idea was to focus on the amenable local quality of life as context for creative individuals to thrive. In Dortmund, Hamburg and Berlin, the projects were shaped from the outset by a cluster approach. Although the McKinsey consultants also interviewed numerous local actors in these cases to identify the most appropriate clusters, they clearly differ from the Goslar/Osterode case. In the cases of Dortmund, Hamburg and Berlin, the consulting solutions provided were all standardized urban future outlines with four or five clusters, each of them enriched with ideas for again four or five key practical projects. Frequently, such project ideas are copied from other places, such as suggesting a targeted cluster management with leadership teams in Hamburg (inspired by Chicago), a delivery unit for startups in Berlin (imitating the one in London) or business plan competitions in Dortmund (copied from Munich). The two probono projects Hamburg and Berlin lasted 6 months, the time apparently required to adapt best-practice models to the local context and to initiate political-economic local relations that

\footnotetext{
${ }^{2}$ All quotes from the interviews and policy documents are translated by the author.
}

may eventually lead to the consultants' advice being implemented.

The Dortmund case, however, also bears some characteristics of process-oriented consulting. The initial 9-month project, financed by the steel and engineering company ThyssenKrupp, was prolonged by a second phase, publicly financed by the city of Dortmund. The reason behind this was the local administration's dissatisfaction with McKinsey having left them on their own with only general ideas and prescriptions. Thus this second phase aimed to implement the clusters, turning the model-oriented consulting project into a process-oriented one. A local officer's assessment of the second phase reveals mutual learning as a general characteristic of process-oriented consulting processes: "This is something that McKinsey had to learn - and did learn in the second phase of cooperation, which is the only phase I can refer to: they learned how important it is to proceed together" (Interview DO15_admin). Learning fundamentally contradicts a clear model orientation in consulting because it requires an exhaustive consideration of the local social, political, historical and economic contexts. A cross analysis of the Dortmund, Essen and Goslar/Osterode cases points to three main lessons that the consultants learned: (1) cooperation, particularly with local officers, but also with entrepreneurs and institutional representatives on all hierarchical levels; (2) communication, from public events to citizen participation; (3) generation of blueprints which the consultancies can apply in future projects. The generation of blueprints in process-oriented consulting builds the basis for future model-oriented consulting, which the following quote pointedly portrays:

They learn through their projects and come up with rules which they transfer to everything. ... The whole thing is taken as blueprint for the next projects - whether the product is the selling of pork sides or a moon landing is basically irrelevant. Well, I am sure that McKinsey can explain the flight to Mars with the three horizons of growth. I am being completely serious. And they would do so in a way that you would instantly say, "Yes, this makes sense". (Interview DO12_proj)

Learning within process-oriented consulting does not take place without conflicts, however, and these are above all also temporal conflicts. When I asked two urban development officers in Essen for the most difficult struggles during the consulting project, their answer was "Schedules. ... Schedules, the whole topic participation" and "Who or which organization, which institutions should be integrated when - so this does not only refer to the participation of citizens" (Interviews E22a\&b_admin). Thus, even within process-oriented consulting, time-consuming actions are avoided as often as possible and were only undertaken when the local administration enforced them (Vogelpohl, 2017). In urban development influenced by consultants, the goal of achieving a fast 
and targeted "politics of delivery" (Raco et al., 2016:216) outweighs the goal of an inclusive and open urban development process. The consultants usually have neither any experience with participation nor any interest in it. The same holds true for a general integration of local or regional knowledge which "McKinsey did not have" and which "also did not excite them" (GOS36b_admin). In all cases, it was the local administration's task to both organize and make use of (vernacular) local knowledge in urban strategic projects engaging management consultancies. Evidently, however, during the processes, the consultants eventually became interested in learning and in gaining knowledge that they then could render generalizable and thus transferable.

\subsection{The moment when the consultants leave: the transition from expert knowledge to political practice}

Through Roland Berger it became unbelievably temporally streamlined. Well, basically a whole strategy process should have been completely realized within 10 months or 8 months, and this in this kind of an urban society. And so it was clear from the beginning that this wouldn't work. And then, eventually, they were simply gone. And I would now say that basically, if we had had more time, we would have been able to reach more people more permanently and not just for short periods but for longer. And I think that would have been more sustainable." (Interview E22a_admin)

The way a consulting project is commissioned and contracted is decisive for the transition from the consulting phase to the daily political and administrative praxis. Three types of transition are discernible in the six cases through the parameter of viability that was addressed in three different ways in the interviews. The process orientation of the two consulting projects in Essen and Goslar/Osterode (and later Dortmund, too) is not a coincidence, but it is an effect of a targeted and well-planned consulting service. A "prepared transition" characterizes these cases. Before the consultants entered the scene, an exhaustive local debate was held on the respective socioeconomic conditions and on possible uses of consultants in each city. Then, an official and detailed tender ensued. To a great extent, the role of the consultants was therefore predefined. This led not only to a clear sharing of tasks between the consultants, local official and politicians but also to building strong self-confidence of all involved local actors in terms of demanding specific services from the consultants or regarding changes during the consulting project. The consultants were not treated as "demigods in black who are able to do everything," as those locally involved sometimes perceived the consultants' self-presentation (Interview DO12_proj). Instead, the planned and tender-based consulting advanced the abovementioned cooperative character of the projects as result of learning processes.
In these cases, preparations were also made for the moment when the consultants leave the scene. The tasks and actions that were to be completed when the consultants were on site were clearly defined and a viable program for the following phase was developed during the consulting process. Concretely, the consultants usually (1) provide analyses of local as well as (inter)nationally comparative data which the local officers lack because of limited time and limited access to databases ("what we as normal staff in the administration collect within four weeks, they did overnight"; Interview GOS36c_admin); (2) moderate internal and public meetings, applying a specific and convincing vocabulary ("their type of moderation is a sort of persuasion"; Interview GOS36c_admin) and (3) organize the building of local networks ("McKinsey is renowned for getting an appointment with anyone"; Interview HH32_consult). However, the goal was also to train the local staff in all these three respects analyzing, moderating, networking - so that key aspects of consulting permanently remain on site.

A clear definition of tasks thus does not contradict the process orientation if process orientation is aimed for and is one of the tasks. In Essen, the whole project was even entitled "strategy process" and, as mentioned above, Roland Berger's pivotal role was "steering processes" (Interview E22b_admin). The quote introducing this chapter, however, shows that even prepared transitions are not necessarily without conflict. However smooth a transition into daily routines is organized, speed obviously remains an issue. Improving a strategy's quality through organizing time-consuming steps like participation and sustaining the processes is eventually left up to local officials and politicians - after the consultants have split the scene.

The consulting projects in Dortmund and Halle ended with a rather "sudden transition". Whereas in these cases the consultants were commissioned against the background of very concrete problems - job losses, plant closures and general deindustrialization, and no specific or even a bad city image - the mission itself was very open. A change was sought and globally operating management consultants seemed to naturally have solutions. In Halle, the guiding, yet open, questions were "What is Halle's main topic? Where should we go? What can we make out of the city? And how can the diverse population identify with the city?" Roland Berger was then approached (Interview HAL26_polit). When Dortmund, suffering from the relocation of a local steel plant to another German city, hired McKinsey, the idea was: "Let's think together with McKinsey about what we can do in Dortmund" (Interview DO16_admin). Besides this decisive openness, local politicians in both cities hoped to gain access, via the consultants, to globally expanding companies that might open a local branch in their city or district.

Even though many conversations took place and interviews were held in both cities, the consultants eventually independently elaborated their own future vision for the cities. In Dortmund, the result was even presented as a "gift" from 
ThyssenKrupp (the company had paid the consultants in the first phase) to the city of Dortmund. Although the concepts were debated and adjusted in the local offices and city councils, the consultants' advice was basically a closed model which was handed over to political and administrative practitioners for implementation. The results were retained by the cities in the form of papers summarizing the recommendations (dortmund project, 2000; Roland Berger, 2002) - a type of material that was superfluous in the process-oriented cases of Essen and Goslar/Osterode.

Significant disappointment on the side of locally involved persons accompanied these sudden transitions. Whereas the recommendations for possible new agencies were relatively clear (a city marketing agency in Halle, an agency for managing the clusters in Dortmund), the other, perhaps more important, goal was not achieved in either case: the initiation of contacts to globally expanding companies. In Halle, Roland Berger was instructed to approach at least 100 companies, but this had no effect. The former contact person in Halle's Department of Business Development (Wirtschaftsförderung) summarizes the situation as follows: "The first disillusioning result was that the action to approach 100 companies led to no tangible results ... Well, my naïve vision concerning this action was that by hiring Roland Berger we were buying the consultants in Europe who have the clients that we need and who utilize the contacts from their other projects for us" (Interview HAL25_admin). In Dortmund, the involved persons were also disappointed by the lack of networking effects they had expected to achieve through collaborating with McKinsey. Additionally, the municipal officers in Dortmund's Business Development department wanted the consultants to take responsibility for the viability of their ideas, resulting in a second round of employing McKinsey that focused on implementing the clusters.

Comparing the prepared and sudden types of transition from the consulting project to daily political praxes shows that expectations are both significantly higher if the transition is not well prepared and are more likely to be left unfulfilled. In contrast, the pro-bono projects follow yet again another logic. Because neither the broader public nor most of the governing politicians are even aware that a consulting project is underway, the pro-bono projects usually end with a "surprising transition", local actors being first confronted with the analyses and advice only in the moment when the end result is presented. The consultants advertise the results via media partnerships, big events and personal networks. Thus, even if the consultants' advice has (usually) ${ }^{3}$ not been solicited, the ensuing media debates assert pressure on governing politicians as well as on the administration. Pro-bono projects aim to arouse the urban public,

\footnotetext{
${ }^{3}$ Sometimes pro-bono projects are also commissioned or organized in close collaboration with the advice seekers. The followup project in Berlin 2013 on the city's startup scene is one example (McKinsey Berlin, 2013).
}

providing consultants with the ability to discursively define local problems and shape possible solutions that it is nearly impossible to ignore. As a person professionally concerned with one of the topics McKinsey focused on in Berlin emphasizes, "We definitely take that seriously and do not ignore it" (Interview B03_proj). Or, as a consultant describes the situation in Hamburg where McKinsey supported the introduction of explicit growth policies in the early 2000s, "That train had left the station. And there were those who also jumped on it, who normally would not have jumped on it" (Interview HH32_consult).

Surprise is indeed the very goal of pro-bono projects which therefore inevitably end with a surprising transition. Topics and problems raised by the consultants thus prompt a political need for action. The way and the extent to which such consulting projects eventually influence political praxis, however, is not predetermined - through neither this type of transition nor others. The type of transition, however, unquestionably shapes the prospects and limitations of consultants' influence on urban policies. The following section analyzes this potential for the six cases, accounting for the temporal aspects of "duration" and "moment of transition" of fast expertise on urban development.

\subsection{Consultants' strategic influence on urban development in times of fast polices}

The consultants' external advice is incrementally adapted during the policy process. In all four non-pro-bono cases, where the consultants were commissioned, regardless whether financed publicly or privately, institutions were set up to stabilize the process of policy changes (see Table 1). In terms of fast policies, simply the fact that renowned consultancies supported policy options produced obvious political pressure to take influential decisions. Irrespective of the duration of the consulting project (from 3 months in Halle to 16 months in Goslar/Osterode), after the consulting project concluded, new administrative arrangements with new organizations were developed. This, however, does not imply that all ideas were generated by the consultants. On the contrary, the consultants' role across all cases is most often described in two variations. First, they are seen as an "accelerator", "intensifier" or "catalyst", whereby the interviewees emphasize that the consultants assembled existing ideas and stimulated their realization through both concrete impulses for action and public attention. The second variation views them as a "moderator" or "prioritizer", whereby the interviewees emphasize that the consultants, with their professional analytical tools, arranged settings for the development of ideas and suggested ways to organize them. In this kind of policymaking, fast is not the copying of mobilized policies to whatever degree but is rather determining which new policies to select and to implement. Consultants thus do not produce but enable a fast policy mode. 
Furthermore, the establishment of organizations potentially entails an increasing dilution of the concrete ideas developed during the consulting project. The four cases in question again reveal two variations. In Essen, a special public agency called City.Agency Essen.2030 (Stadt.Agentur Essen.2030) was spun off the Department for Urban Planning. The five foci of the Essen.2030 strategy - "urban, successful, talented, diverse, dedicated" - initially included project ideas, but now the City.Agency serves rather as a corridor for projects that were not selected during the consulting project. Although the local partners in Essen appreciated that the consultants assumed the moderation, they were very keen to limit the consultants' role to such a function and instead allowed urban politicians and urban citizens develop concrete plans for Essen. A similar process took place in Halle, where the very concrete advice to set up Halle City Marketing was given. Its first chief executive, however, used Roland Berger's concrete project suggestions as a pool for ideas instead of as a program. In his words: "It certainly built a basis, a foundation, but it is not the building we built upon it" (Interview HAL27_proj).

In contrast to creating a pool for potential projects, training local administrative staff was a huge aspect of consulting projects in Dortmund and Goslar/Osterode. The staff working in the new institutions dortmund project and IZH learned some of the consultants' methods and approaches - an effect that offers a sharp contrast to the few other studies on consultants in urban policy that found long-term outsourcing of certain public tasks and expertise in the UK (Raco et al., 2016; Parker et al., 2014). After the consulting projects in Dortmund and Goslar/Osterode ended, consulting methods continued to be applied so that the consulting's effect can be seen in the introduction of another style of policy implementation. This style includes a professional project management with a foremost focus on business development. An officer of today's IZH explains the effect: "The state government said, 'No, we do not want a paper. We want to search for another way. We must train the people here so that they have better management knowledge.", With a laugh, a colleague continued: "That is why we said: our training cost 1 million for each of us!" (Interviews GOS36a\&b_admin). The officers affirm that they learned not only a more target-oriented way of proceeding but also another manner of approaching local entrepreneurs. In Dortmund, where the project was already initiated 15 years ago, an officer endorsed the effect of such a strategy: "It was a form of professionalizing business development.... The most valuable benefit was that slowly, very slowly but also continuously, structures were produced ... for a development which has come to fruition only now" (Interview DO13_admin).

Establishing an organization which eventually operates without the consultants does, however, not mean that the consulting project had no influence on the policies themselves. Acceleration and prioritization implies a selection of key topics which, in most cases, solely revolve around economic growth. Results were mostly a cluster orientation and/or branding activities. Such foci were also fueled by the pro-bono projects in Hamburg and, to a lesser extent, in Berlin. In Hamburg, the pro-bono project paved the way for a decisive cluster orientation by starting a public debate on the need for more targeted and cluster-oriented growth policies (McKinsey Hamburg, 2001). McKinsey timed their project to coincide with the local elections in 2001, generating a broad debate on the state of Hamburg's economic performance and forcing the newly elected government to react (Vogelpohl, 2016). In Berlin, the project was also timed with the city-state elections of 2011, confronting the government with numbers on actual and potential economic development. A critic states, "It is not a Berlin study. At best, it is a sort of potential study for a business location" (Interview B09_crit). The exact prognosis supplied by McKinsey of 100000 possible new jobs in Berlin by 2020 (McKinsey Berlin, 2010) was most frequently cited in the media. Combined with direct interactions with the local economic, cultural and political elite, pro-bono projects rely on public debates to create a political necessity to act. In both cities, Hamburg and Berlin, a strategy process was initiated in the aim of establishing a new urban development model (Leitbild) which either resembled McKinsey's advice (das Leitbild Wachsende Stadt; FHH, 2002) or whose design included input from a McKinsey consultant amongst others (Stadtforum 2030 Berlin $^{4}$ ).

Across all cases, one effect of consulting that most interviewees appreciated was the stimulus for change. This temporary stimulus was generated through the creation of an extraordinary situation - a world-renowned consultancy is working on "our" urban future. Simply the reputation of the consultancies (be it positive or negative) fueled a strong reaction. A former politician in Halle assesses the largest benefit as "a certain weight of the discussion because it was Roland Berger" (Interview HAL26_polit). In the four cases where the consultancies were commissioned, it was also extraordinary that different local people came together with external experts to think about strategies for the city's future. During the relatively short consulting projects, much energy and personnel were dedicated to a debate about future possibilities, generating a spirit of optimism. However, often both grandiose ideas and very high expectations were nurtured within this period, many of which then turned out to be unrealistic or too ambitious. Asked for the project's key impacts, a former local officer in Dortmund responded:

The expectations that McKinsey stimulates, but cannot satisfy. Well, that is positive and negative; my attitude is a little ambivalent here. Initially, you can use the expectations to generate a drive and to acquire resources. But you must be terribly careful that disappointments do not follow very quickly

\footnotetext{
${ }^{4}$ www.stadtentwicklung.berlin.de/planen/ stadtentwicklungskonzept/download/stadtforum/2013-04-24_ Dokumentation_SF1_DS_BF.pdf, accessed 6 April 2016.
} 
afterwards. Well, the chief manager of the [organization], who was very supportive in the beginning, very quickly changed his mind. After a year or so all he said was, "Keep the Mackies ${ }^{5}$ off my back!" (Interview DO16_admin)

To sum up, the fast consulting projects served as stimuli and created a situation to plan future-oriented policies. Quickly afterwards, however, policymaking slows down and meets the everyday political reality - council decisions, oppositional critique, funding gaps, etc. This deceleration did not above all signal a delay, but instead it revealed the selectivity of the consultants' advice and opened the debate up for other local needs concerning, for example, housing, environmental issues or diversity. Nevertheless, new topics and partly new organizations have emerged in these cities, whose long-term impacts are only recognizable many months and years later. Even a consultant identifies speed as major problem: "Well, I think it was the pace of implementation.... I think you must accept that, though I have difficulties with it. But it simply takes incredibly long for something to happen in public life" (Interview HH32_consult).

\section{Conclusion}

By fueling a pressure to act, management consultants accelerate urban policymaking. In all six cases, consultancy projects provoked new debates on future strategies for cities that were usually followed by concrete policies. Additionally, after the consultants' engagement and even in times of austerity, new special agencies are quickly established - or more accurately, it is precisely in times of austerity when local powers and resources are increasingly concentrated. As for the new policies, two general effects of consulting projects are discernible. On the one hand, processes and project management are professionalized, most often accompanied by a clear concentration of the policy agenda on economic growth. On the other hand, models that proved successful elsewhere are adopted and adapted, i.e., clusters and city marketing. So, the "silver-bullet policies" that Peck and Theodore (2015:xv) identify as content of fast (urban) policy are only one aspect. Another version of accelerating and accelerated policy is a structured, prioritizing, efficiencyoriented approach to policymaking itself, which is widely understood as professionalization. This professionalization, however, is only possible in an ambivalent amalgamation of selectively determined themes and involved persons. As the problems with participation have shown, the inclusion of many local stakeholders and citizens impedes fast and targeted decisions that professionalization aims for. Furthermore, the clear focus on city marketing, cluster and economic growth neglects the complexity of the urban and marginalizes other themes (like housing or ecology) in consulting-led spatial strategies.

\footnotetext{
${ }^{5}$ Diminutive for the McKinsey consultants
}

The above analysis of the role of management consultants in urban development in times of fast policies hints at wider current urban conditions. First, it problematizes who is legitimated and is able to develop ideas and plans for future urban development. The fact that international consultants have acquired a more central role in thinking about urban futures and are sometimes even invited to do so at the center of local power structures points to the question of who is not involved. Whereas consultants cooperate with local business elites as much as with governing politicians and sometimes work in, for example, key administrative buildings, groups like local initiatives of social movements or social communities rarely gain access to these structures. Even though cooperating with the powerful elite might not be the goal of social movements, the lack of access implies that their voice is not respected as much as the voice of international experts. The role of local groups and citizens thus should be strongly considered and intensified in future urban consulting projects if urban policies are designed to improve the people's daily life.

Second, experts such as management consultants fuel fast policies, although they often do not produce or introduce them. Whereas they actively aim to prompt political decisions in pro-bono projects, such as in Hamburg and Berlin, their invited role to accelerate policymaking was even more significant in the other cases. Management consultants are thus not always drivers, but serve more often as vehicles for fast policies. More generally, my analysis shows that experts give rise to fast urban policies and fast urban policies give rise to experts, and vice versa. As long as local policymaking is increasingly related to international developments and fashions and as long as some sort of urban crisis is perceived by local politicians, the mutually reinforcing interrelationship between experts and fast policies will become ever more relevant.

Third, the large management consultancies in focus here are a key influence on strategic urban development in terms of long-term visions for cities. They are neither commissioned nor proactive in other urban plans like the development of a new site, the relocation of an institution or the development of future ideas on the neighborhood scale (though such kinds of influence certainly exist with other types of consultants such as planning experts or professional moderators). In the cases I studied, management consultants' strategic relevance lies in their ability to influence the interrelationship between urban policy and urban politics: the consultants are used to build networks among the local elite and decision makers, shaping the topics local actors wish to highlight. Thus, the corridors for future urban development that are built with the help of management consultants often represent only a small part of urban policy topics. Nevertheless, cases like Essen show how the consultants' influence can be reduced. Without the strong effort and the clear will of the locally involved, however, a broadening of themes and a broad participation of urban citizens is unlikely when urban strate- 
gies are developed with the help of management consultants. Alongside the need for the role of local groups and citizens to be intensively reflected on, the specific role that consultants do and should fill also needs to be part of a wider urban debate.

Fourth, the analysis indicates that the status of expert knowledge itself is not only to explain local problems but also to provide appropriate solutions. In the case of management consultants, the experts' style of organizing topics, their labeling and framing of them is equally important. Resch (2005:23) emphasizes that it is not the exclusivity of knowledge that is most important, but instead its non-binding nature, its short-term nature and its plausibility provides its legitimation. Management consultants exert their influence on strategic urban development through the way they present knowledge plausibly in order to convince, even persuade a heterogeneous urban society to support the fast designed urban future visions. Whereas this style obviously initiates new urban policy plans, it does not guarantee the viability of the consultants' advice. Particularly the disappointment by the local administration in the Halle and Dortmund cases shows that short-term projects often cannot provide a robust basis for long-term, inclusive and thus lengthy policy processes. This eventually indicates that the "politics of delivery" (Raco et al., 2016:216) produced by consultants achieves to provide quick, but not necessarily viable, solutions as a key aspect of the interconnection of accelerated temporality and expertise.

\section{Data availability}

The qualitative data underlying this paper are not publicly available. For further information please contact the author.

Competing interests. The author declares that she has no conflict of interest.

Acknowledgements. I wish to thank all intereviewees who took their time to provide insights into consulting processes in cities. I am also grateful to the two anonymous reviewers for the helpful comments on an earlier draft of this article. For making this work possible, I thank the German Research Fund DFG.

Edited by: J. Wintzer

Reviewed by: two anonymous referees

\section{References}

Baker, T. and Ruming, K.: Making "Global Sydney”: Spatial Imaginaries, Worlding and Strategic Plans, Int. J. Urban Regional, 39, 62-78, doi:10.1111/1468-2427.12183, 2015.

Belina, B., Heeg, S., Pütz, R., and Vogelpohl, A.: Neuordnungen des Städtischen im neoliberalen Zeitalter - Zur Einleitung, Geogr. Z., 101, 125-131, 2013.
Bill, H. and Falk, S.: Unternehmensberatungen in der Politikberatung, in: Handbuch Politikberatung, edited by: Falk, S., Rehfeld, D., Römmele, A., and Thunert, M., VS, Wiesbaden, 290-299, 2006.

Bischoff, J.: Dauerzustand Schuldenkrise - Die endlose Kurzfrist"Reparatur" des Euro-Systems, Supplement der Zeitschrift Sozialismus, 2012.

Bitterer, N. and Heeg, S.: Die Macht der Zahlen: Kalkulative Praktiken in der Immobilienwirtschaft, Z. Wirtsch., 59, 34-50, 2015.

Brenner, N., Peck, J., and Theodore, N.: Variegated Neoliberalization - Geographies, Modalities, Pathways, Global Networks, 10, 182-222, doi:10.1111/j.1471-0374.2009.00277.x, 2010.

Dolowitz, D. P. and Marsh, D.: Learning from Abroad: The Role of Policy Transfer in Contemporary Policy-Making, Governance, 13, 5-23, doi:10.1111/0952-1895.00121, 2000.

dortmund project: Das Zukunftspaket - Dortmunds Sprung in die Informations- und Wissensgesellschaft, Dortmund, 2000.

Einig, K., Grabher, G., Ibert, O., and Strubelt, W.: Urban Governance, Informationen zur Raumentwicklung, 2005, I-IX, 2005.

FHH, Free and Hanseatic City of Hamburg: Leitbild: Metropole Hamburg - Wachsende Stadt, Drucksache 2002/0672, Hamburg, 2002.

Göddecke-Stellmann, J.: Politikberatung in der Raum- und Stadtentwicklung, Informationen zur Raumentwicklung, 2011, I-III, 2011.

Harvey, D.: From Managerialism to Entrepreneurialism - The Transformation in Urban Governance in Late Capitalism, Geogr. Ann. B, 71, 3-17, doi:10.2307/490503, 1989.

Harvey, D.: Spaces of Neoliberalization: Towards a Theory of Uneven Geographical Development, Hettner Lecture 2004, Steiner, Stuttgart, 2004.

Hurl, C.: Disassembling Policy Pipelines: Unpacking the Work of Management Consultants at Public Meetings, Geogr. Helv., accepted, 2017.

Jonas, M.: The Dortmund Case: On the Enactment of an Urban Economic Imaginary, Int. J. Urban Regional, 38, 2123-2140, doi:10.1111/1468-2427.12092, 2014.

Kipping, M. and Wright, C.: Consultants in Context: Global Dominance, Societal Effect, and the Capitalist System, in: The Oxford Handbook of Management Consulting, edited by: Kipping, M. and Clark, T., Oxford University Press, Oxford, New York, 165185, 2012.

Kuus, M.: For Slow Research, Int. J. Urban Regional, 39, 838-840, doi:10.1111/1468-2427.12257, 2015.

Läpple, D.: Städtische Arbeitswelten im Umbruch - Zwischen Wissensökonomie und Bildungsarmut, in: Das Neue Gesicht der Stadt - Strategien für die urbane Zukunft im 21. Jahrhundert, edited by: Heinrich-Böll-Stiftung, Berlin, 19-35, 2006.

MacLeavy J. : A "New Politics" of Austerity, Workfare and Gender? The UK Coalition Government's Welfare Reform Proposals, Cambridge Journal of Regions, Economy and Society, 4, 355367, doi:10.1093/cjres/rsr023, 2011.

MacLeod, G.: Urban Politics Reconsidered - Growth Machine to Postdemocratic City?, Urban Studies, 48, 2629-2660, doi:10.1177/0042098011415715, 2011.

McCann, E.: Urban Policy Mobilities and Global Circuits of Knowledge: Toward a Research Agenda, Ann. Assoc. Am. Geogr., 101, 107-130, doi:10.1080/00045608.2010.520219, 2011. 
McCann, E. and Temenos, C.: Mobilizing Drug Consumption Rooms: Inter-Place Networks and Harm Reduction Drug Policy, Health and Place, 31, 216-223, doi:10.1016/j.healthplace.2014.12.009, 2015.

McKinsey Hamburg: Hamburg Vision 2020 - Vom nationalen Zentrum zur Europäischen Metropole, Hamburg, 2001.

McKinsey Berlin: Berlin 2020 - Unsere Stadt. Wirtschaftliche Perspektiven durch neue Wachstumskerne, McKinsey \& Company, Berlin, 2010.

McKinsey Berlin: Berlin gründet - Fünf Initiativen für die Start-upMetropole Europas, McKinsey \& Company, Berlin, 2013.

Mitchell, T.: How Neoliberalism Makes its World - The Urban Property Rights Project in Peru, in: The Road from Mont Pèlerin - The Making of the Neoliberal Thought Collective, edited by: Mirowski, P. and Plehwe, D., Harvard University Press, Cambridge, Mass., 386-416, 2009.

Nentwig-Gesemann, I.: Die Typenbildung der dokumentarischen Methode, in: Die dokumentarische Methode und ihre Forschungspraxis - Grundlagen qualitativer Sozialforschung, edited by: Bohnsack, R., Nentwig-Gesemann, I., and Nohl, A.-M., Springer VS, Wiesbaden, 294-323, 2013.

Nohl, A.-M.: Interview und dokumentarische Methode: Anleitungen für die Forschungspraxis, Springer VS, Wiesbaden, 2012.

Parker, G., Street, E., Raco, M., and Freire-Trigo, S.: In Planning we Trust? Public Interest and Private Delivery in a Co-managed Planning System, Town and Country Planning, 83, 537-540, 2014.

Peck, J.: Constructions of Neoliberal Reason, Oxford University Press, Oxford, New York, 2010.

Peck, J.: Austerity urbanism, City, 16, 626-655, doi:10.1080/13604813.2012.734071, 2012.

Peck, J. and Theodore, N.: Mobilizing Policy - Models, Methods and Mutations, Geoforum, 41, 169-174, doi:10.1016/j.geoforum.2010.01.002, 2010.

Peck, J. and Theodore, N.: Fast Policy - Experimental Statecraft at the Thresholds of Neoliberalism, University of Minnesota Press, Minneapolis, London, 2015.

Petts, J. and Brooks, C.: Expert Conceptualisations of the Role of Lay Knowledge in Environmental Decisionmaking: Challenges for Deliberative Democracy, Environ. Plann. A, 38, 1045-1059, doi:10.1068/a37373, 2006.

Prince, R.: Policy Transfer, Consultants and the Geographies of Governance, Prog. Hum. Geog., 36, 188-203, doi:10.1177/0309132511417659, 2012.

Raco, M.: State-led Privatisation and the Demise of the Democratic State - Welfare Reform and Localism in an Era of Regulatory Capitalism, Ashgate, Farnham, Burlington, 2013.
Raco, M., Street, E., and Freire-Trigo, S.: The New Localism, AntiPolitical Development Machines, and the Role of Planning Consultants: Lessons from London's South Bank, Territory, Politics, Governance, 4, 216-240, doi:10.1080/21622671.2015.1036912, 2016.

Rehfeld, D.: Grenzen wissenschaftlicher Politikberatung - Überlegungen zur zeitlichen Dimension am Beispiel der Strukturpolitik, in: Glanz und Elend der Politikberatung, edited by: Jens, U. and Romahn, H., Metropolis, Marburg, 129-147, 2005.

Resch, C.: Berater-Kapitalismus oder Wissensgesellschaft? Zur Kritik der neoliberalen Produktionsweise, Westfälisches Dampfboot, Münster, 2005.

Roland Berger: Abschlußbericht Investorenansiedlungs- und Stadtmarketingkonzept, Halle, 2002.

Rügemer, W.: Beraten und verkauft: Die Kommunen, in: Die Berater - Ihr Wirken in Staat und Gesellschaft, edited by: Rügemer, W., transcript, Bielefeld, 175-197, 2004.

Saint-Martin, D.: Governments and Management Consultants: Supply, Demand, and Effectiveness, in: The Oxford Handbook of Management Consulting, edited by: Kipping, M. and Clark, T., Oxford University Press, Oxford, New York, 447-464, 2012.

Schützeichel, R.: Beratung, Politikberatung, wissenschaftliche Politikberatung, in: Politikberatung, edited by: Bröchler, S. and Schützeichel, R., Lucius \& Lucius, Stuttgart, 5-32, 2008.

Sinz, M.: Raumordnung als Gegenstand von Politikberatung - ein Erfahrungsbericht, Informationen zur Raumentwicklung, 2011, 471-486, 2011.

Vogelpohl, A.: McKinseyization or Governmental Policy? Management Consultancies in Urban Development Strategies. The Case "Metropolis Hamburg - Growing City", Raumforschung und Raumordnung, doi:10.1007/s13147-016-0461-0, 2016.

Vogelpohl, A.: The Politics of Consultation in Urban Development and its Encounters with Local Administration, in: The Urban Political: Ambivalent Spaces of Late Neoliberalism, edited by: Enright, T., and Rossi, U., Palgrave Macmillan, Basingstoke, New York, in press, 2017.

Wiechmann, T.: Planung und Adaption - Strategieentwicklung in Regionen, Organisationen und Netzwerken, Rohn-Verlag, Dortmund, 2008. 